\title{
Performance of a large partial-depth guide wall to divert downstream migrating Atlantic salmon smolts at Tuilières dam, Dordogne River
}

\author{
Michel Larinier ${ }^{1, *}$, Lionel Dumond ${ }^{2}$, Thierry Lagarrigue ${ }^{3}$, Aurélien Frey $^{3}$ and François Travade ${ }^{4}$ \\ 1 22, impasse Léonard André Bonnet, 12100 Millau, France \\ ${ }^{2}$ Electricité de France CIH, 4 rue Claude Marie Perroud, 31096 Toulouse cedex, France \\ ${ }^{3}$ ECOGEA, 352, avenue Roger Tissandié, 31600 Muret, France \\ 4 24, rue Edgar Faure, 75015 Paris, France
}

Received: 19 October 2019 / Accepted: 29 February 2020

\begin{abstract}
From 2010 to 2016, an evaluation of the performance of a partial-depth guide wall associated with three surface bypasses to ensure the safe downstream migration of Atlantic salmon smolts was conducted at the Tuilières power plant on the Dordogne River in southwestern France. The objectives of this study, during which 603 smolts were monitored using radio telemetry, were (i) to determine their escapement rate (passage through routes other than turbines), (ii) to analyse their behaviour faced with the structure and (iii) to assess the permeability of the guide wall as a function of turbine and spilling flows. The rate of escapement through the surface bypass routes varied from approximately $15 \%$ to $85 \%$. The turbine flow was the main factor influencing the guide wall efficiency. The contribution of secondary bypasses, while significant for low flows, decreased rapidly with the increase in turbine flows. The vast majority of fish arrived on the two downstream bays of the wall or directly in the area of the main bypass, with the guiding effect of the guide wall becoming less noticeable with the increase of turbine flow. A modification of the depth of the guide wall in 2014 slightly improved its efficiency (by 5-10\%) for low turbine flows. Logistic regression models were used to describe the evolution of the efficiency of the facilty as a function of the turbine flow and the probability of direct passage under a bay as a function of average velocity under this bay.
\end{abstract}

Keywords: Atlantic salmon smolts / downstream migration / behaviour / hydroelectric plant / guide wall / radio-tracking

Résumé - Efficacité d'un mur guideau de surface destiné à guider les smolts de saumon atlantique en migration de dévalaison au barrage de Tuilières sur la Dordogne. De 2010 à 2016 une évaluation des performances d'un mur guideau associé à des exutoires de surface visant à assurer la dévalaison sans dommage des smolts de saumon atlantique a été menée à la centrale hydroélectrique de Tuilières sur la rivière Dordogne dans le Sud-Ouest de la France. Cette étude, au cours de laquelle 603 smolts ont fait l'objet d'un suivi par radio télémétrie, avait pour objectifs i) d'évaluer les taux d'échappement (passages par d'autres voies que par les turbines) ii) d'analyser le comportement des smolts devant les ouvrages ainsi que (iii) l'évolution de la perméabilité du masque de guidage en fonction des conditions de débit turbiné et de débit déversé au barrage. Le taux d'échappement par les exutoires a varié de $15 \%$ à $85 \%$. Le débit turbiné est le facteur principal influant sur l'efficacité du mur guideau. L'apport des exutoires secondaires, s'il est notable pour les faibles débits turbinés, diminue fortement avec l'augmentation de ces débits. Les poissons arrivent en grande majorité sur les travées aval du masque ou directement à proximité de l'exutoire principal, l'effet guidage du masque diminuant avec le débit turbiné. Une modification de la profondeur d'immersion du masque en 2014 n'améliore son efficacité (de $5 \%$ à $10 \%$ ) que pour les faibles débits turbinés. Des régressions logistiques ont été utilisées pour décrire l'évolution de l'efficacité du dispositif en fonction du débit turbiné ainsi que la probabilité de passage direct sous le mur en fonction de la vitesse moyenne dans la travée.

\footnotetext{
*Corresponding author: michel.larinier@orange.fr
} 


\begin{abstract}
Mots-clés : Smolts de saumon atlantique / migration de dévalaison / comportement / centrale hydroélectrique / mur guideau / radio-télémétrie
\end{abstract}

\section{Introduction}

Dams, particularly hydroelectric developments, fragment rivers and streams, which can lead to the reduction or even extinction of certain populations of migratory fish. In Europe, for example, the populations of various diadromous species have decreased significantly as a result of the multiplication of hydroelectric developments since the end of the 19th century (Limburg and Waldman, 2009). These developments represent a major problem, not only for upstream migration by blocking access to feeding, spawning and refuge areas, but also for downstream migration. In varying degrees, dams can result in direct or delayed mortality during the transit of migrants (juveniles and/or adults) through spillways or turbines, as well as delays in their migration. Dam effects are cumulative when several obstacles are present on the same migration route (Larinier, 2008; Thorstad et al., 2012, 2017). The problems associated with downstream migration have not been as well studied or fully considered as those associated with upstream migration. However, research has intensified over the past 40 years, first in North America (Clay, 1995), and much more recently in Europe (over the past 25 years in France), on the mitigation of the negative effects of hydropower developments on downstream fish migration. As an initial mitigation measure, conventional turbines can be replaced with fishfriendly turbines, which by their design (large diameter, low number and large clearance of blades, low impact velocity, etc.) minimize fish injuries for individuals using this potential migration route, such as Archimedes screws or VLH (Very Low Head) turbines (Cefas, 2012; Lagarrigue, 2013; Lagarrigue and Frey, 2010). Other techniques, such as surface bypasses, associated with conventional water intake trash racks, have proven to have highly variable and generally limited efficacy (Larinier and Travade, 1999; Tomanova et al., 2018; Ovidio et al., 2017). Passage efficiency of surface bypasses is linked not only to the spacing of the bars, but also to the existence of a velocity pattern in front of the rack guiding the fish to the entrance of the bypass. As a result, fish-friendly trash racks associated with one or more surface bypasses have been proposed more recently (Courret and Larinier, 2008; Calles et al., 2013; Nyqvist et al., 2017). These intake racks, closely spaced, sloped or angled, guide fish to one or more surface bypasses that allow the fish to circumvent the power plant and the turbines. However, these solutions are so far limited, in any case in France, to small hydroelectric power plants with turbine flows of less than a hundred $\mathrm{m}^{3} / \mathrm{s}$ (Tomanova et al., 2018). For larger power plants, the installation of trash racks (sloped or angled) with reduced spacing can induce high construction costs, but also the loss of flow due to clogging and heavy maintenance constraints (Odeh, 1999). On such installations, and for surface-oriented migratory species, facilities for downstream migration of smolts combining a partial-depth guide wall and a surface bypass are frequently mentioned in the literature (Odeh and Orvis, 1998; Larinier and Travade, 1999; Calles et al., 2013).
However, there have been few evaluations of such systems to date, and there are still no clear design criteria. Therefore, whether or not this type of guidance facility could be considered a solution to rehabilitate downstream passages remains to be evaluated (Mulligan et al., 2017, 2018; Calles et al., 2013).

The first dams built on the Dordogne river at the end of the 19th century caused the extinction of most diadromous fish populations in the whole basin. A salmon reintroduction plan was launched in 1975 by the French Ministry of the Environment on the Dordogne basin. In particular, this plan resulted in a working policy aimed at restoring upstream migration and allowing anadromous migratory species to regain access to the still existing spawning grounds. Upstream fish facilities have been installed on the three main obstacles to migration, the Bergerac (1985), Mauzac (1987) and Tuilières (1989) hydroelectric power plants (Travade et al., 1998). The issue of downstream migration at these same sites has been addressed more recently.

The Tuilières hydroelectric facility is a strategic site in terms of the downstream migration of Atlantic salmon smolts, with a mean mortality rate due to transit through the turbines estimated at $12 \%$ of the stock (Travade et al., 1987; Larinier and Dartiguelongue, 1989), which represents $50-70 \%$ of the total mortality due to hydroelectric facilities in the basin (Pallo and Larinier, 2002). A downstream migration facility with the installation of a new angled trashrack with reduced bars spacing guiding the smolts towards bypasses was initially considered. Concerned about possible maintenance problems and the peculiarity of the hydraulic conditions in the forebay, Electricity of France (EDF) opted for the installation of a partial-depth wall to achieve this guiding effect towards surface bypasses. The competent authorities accepted this alternative, provided that the performance of the facility is assessed and its efficiency demonstrated.

A partial-depth guide wall designed to divert downstream migrating smolts towards three surface bypasses was installed in 2009. This facility, the first of its kind to be installed in France, was evaluated by radio telemetry during the smolt migration season from 2010 to 2016 .

\section{Material and methods}

\subsection{Study site: the powerhouse and the flood gates}

The Tuilières hydroelectric facility is located on the Dordogne River (France), approximately $200 \mathrm{~km}$ from the estuary (Fig. 1). The mean annual flow is $275 \mathrm{~m}^{3} / \mathrm{s}$. The mean daily flow during the period of smolts downstream migration (mid-March to mid-June) is $276 \mathrm{~m}^{3} / \mathrm{s}$, the median, $1 \mathrm{st}$ and 3rd quartiles are respectively $216 \mathrm{~m}^{3} / \mathrm{s}, 141 \mathrm{~m}^{3} / \mathrm{s}$ and $360 \mathrm{~m}^{3} / \mathrm{s}$. The plant consists of a $105 \mathrm{~m}$ wide spillway located on the left bank side and a $70 \mathrm{~m}$ wide run-of-river hydroelectric power plant located on the right bank side. Under normal operations water levels in the reservoir above the dam fluctuate only a few 
centimetres. The spillway consists of 8 bays equipped with Stoney gates $13.90 \mathrm{~m}$ high and $10 \mathrm{~m}$ wide except for the bay 8 (counting from the left bank) which is $7 \mathrm{~m}$ wide (Fig. 2). Bays 5 to 8 are also equipped with surface flap gates. The eighth flap gate (FG), $5.5 \mathrm{~m}$ wide, acts as the main downstream bypass and can deliver a flow rate of $21 \mathrm{~m}^{3} / \mathrm{s}$ while the next three flap gates are limited to $16 \mathrm{~m}^{3} / \mathrm{s}$. The reservoir created by the dam has an area of about 75 ha and a volume of about $5 \times 10^{6} \mathrm{~m}^{3}$.

The powerhouse contains eight Kaplan turbines with a total generating capacity of $37 \mathrm{MW}$. Each unit can pass $52 \mathrm{~m}^{3} / \mathrm{s}$ under the maximum net head of $12.40 \mathrm{~m}$. The total hydraulic capacity of the powerhouse is limited to about $320 \mathrm{~m}^{3} / \mathrm{s}$. The water intake of the powerhouse is protected by a $60 \mathrm{~m}$ long and $7.7 \mathrm{~m}$ high bar screen, consisting of rectangular bars spaced $70 \mathrm{~mm}$. The maximum approach velocity of flow to the trash rack (turbine flow to trash rack area ratio) is $0.7 \mathrm{~m} / \mathrm{s}$ when the plant is operating at full load. A fish elevator was installed in 1989 on the right bank of the plant. The discharge at its entrance varies from $1.5 \mathrm{~m}^{3} / \mathrm{s}$ to $4.5 \mathrm{~m}^{3} / \mathrm{s}$ according to the downstream water level. This elevator is coupled with a $60 \mathrm{~m}$ long underground, vertical slot fish pass that allows fish to cross the powerhouse. The fish pass exit is located approximately $40 \mathrm{~m}$ upstream of the plant intake. This fish pass is fed by a discharge of about $0.6 \mathrm{~m}^{3} / \mathrm{s}$.

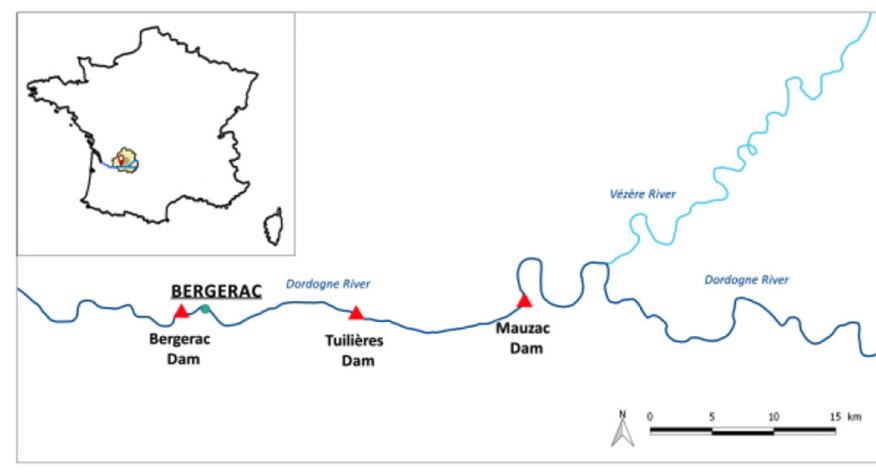

Fig. 1. Location of the Tuilières hydroelectric plant on the Dordogne River.

\subsection{Study site: the guide wall and the surface bypasses}

The downstream migration facility consists of a partialdepth guide wall, aimed at guiding downstream migrating smolts either to the surface flap gate (FG) constituting the main surface bypass, or to two intermediate secondary surface bypasses (SBP) located in the wall (SBP1 and SBP2) (Fig. 3). Secondary bypass 1 (SBP1) is located approximately at the end of the upstream third of the wall, secondary bypass 2 (SBP2) after two-thirds of the wall. The guide wall consists of a $126 \mathrm{~m}$ long concrete structure supporting solid metal plates plunging to a depth of $4.07 \mathrm{~m}$, which ensures a $5.15 \mathrm{~m}$ high opening between the lower end of the wall and the bottom of the forebay for the flow to the units. The initial intent was to design a vertical and rectilinear guide wall along its entire length. However, one main constraint affected its final design: the potential need for replacing this wall with a conventional trash rack with rectangular bars spaced $20 \mathrm{~mm}$ in case the efficiency of the guide wall was considered unsatisfactory. This resulted in (i) the installation of an oversized civil engineering structure for the wall, capable of supporting the bar screen and the trash rakes to ensure its maintenance, (ii) a $17^{\circ}$ vertical inclination of the wall metal plates, which is essential when installing trash racks, (iii) a discontinuity in the wall profile between its upstream part, inclined relative to vertical, and its vertical end part at the dam connection.

The wall is divided into three bays (from upstream to downstream T1, T2 and T3) of about $35 \mathrm{~m}$ each. The free passage sections under these three bays are respectively $170 \mathrm{~m}^{2}, 155 \mathrm{~m}^{2}$ and $141 \mathrm{~m}^{2}$. The average flow velocity under the bays (turbine flow to total passage area ratio) is about $0.20 \mathrm{~m} / \mathrm{s}$ for a turbine flow of $100 \mathrm{~m}^{3} / \mathrm{s}$ and $0.70 \mathrm{~m} / \mathrm{s}$ for the maximum turbine flow. Actually, measurements on the scale model used to design the project at the EDF National Hydraulics Laboratory (LNHE) in Chatou showed that at the maximum capacity of the plant $\left(320 \mathrm{~m}^{3} / \mathrm{s}\right)$, the downstream bay $\mathrm{T} 3$ concentrated $47 \%$ of the flow, while $\mathrm{T} 1$ and $\mathrm{T} 2$ bays were limited to $25 \%$ and $28 \%$. The average flow velocities under bays T1, T2 T3 at the maximum capacity were $0.48 \mathrm{~m} / \mathrm{s}$, $0.59 \mathrm{~m} / \mathrm{s}$ and $1.09 \mathrm{~m} / \mathrm{s}$ respectively. The upstream section of the wall has an inclination of $56^{\circ}$ to the direction perpendicular to the plant trash rack, with the next two sections being less
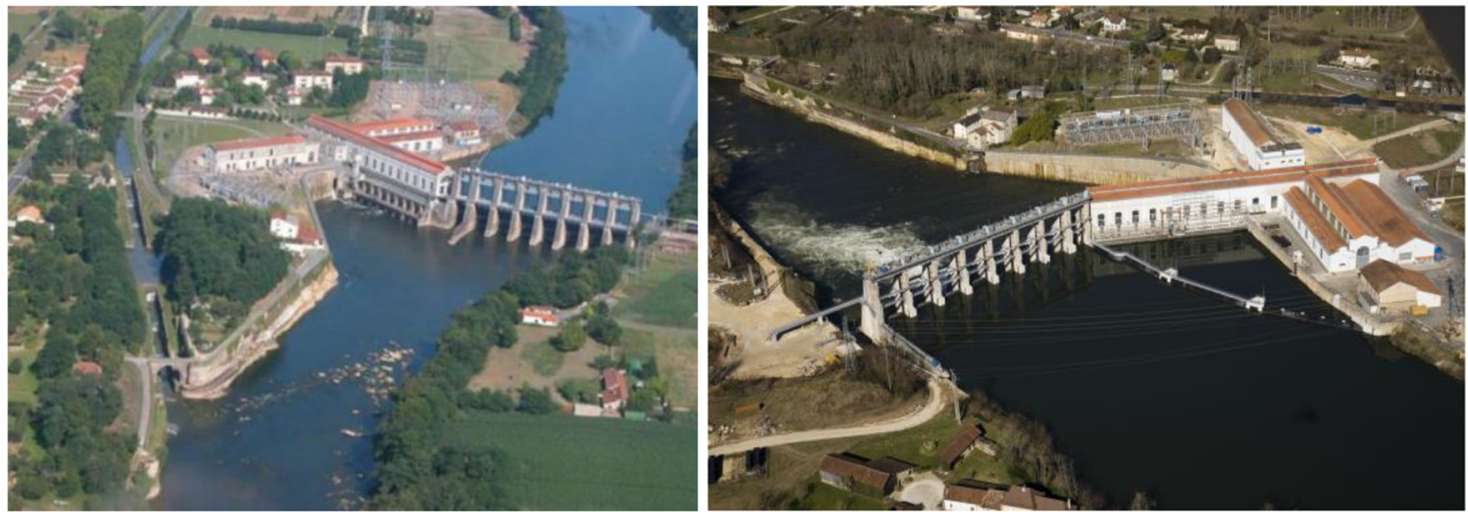

Fig. 2. General views of the Tuilières powerplant. 


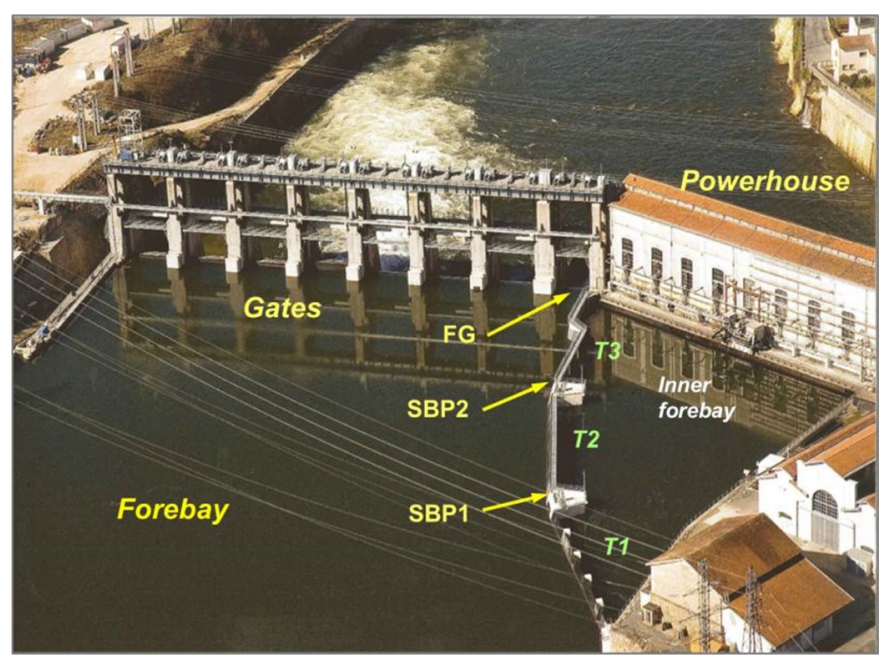

Fig. 3. View of the guide wall and location of the bypasses (FG: flap gate; SBP1 and SBP2: secondary bypasses 1 and 2; bays T1, T2 and $\mathrm{T} 3)$.

inclined, with angles close to $42^{\circ}$ and $30^{\circ}$ respectively. The downstream section is perpendicular to the axis of the flood gate section (Fig. 3). The downstream end of the guide wall is adjacent to the main bypass entrance (existing flap gate FG). The two secondary bypasses (SBP1 and SBP2) are located between the two upstream bays in towers enclosing wells that allow the flow to be evacuated. These bypasses have a width of $3.5 \mathrm{~m}$ for a height of $2.5 \mathrm{~m}$. The flow rate supplying each secondary bypass is around $2.5 \mathrm{~m}^{3} / \mathrm{s}$. The wells are extended by two large ducts that connect to the bottom of the reservoir and release flow downstream of the fish elevator. The entrances of the two secondary bypasses are equipped with round-section protection bars with 13 centimetres spacing.

Following the mixed results of the first years of monitoring, the studies on the physical model were reactivated at the LNHE, which led to modifications of the guide wall during the summer of 2013: the wall of the median section was lowered by $0.85 \mathrm{~m}$, that of the downstream section by $1.65 \mathrm{~m}$, the upstream section remaining unchanged. Measurements showed a more uniform repartition of the flow between the three bays T1 (30\%), T2 (30\%) and T3 (40\%), than before modification. At maximum capacity, the corresponding average flow velocity under bays $\mathrm{T} 1, \mathrm{~T} 2$ and $\mathrm{T} 3$ were $0.57 \mathrm{~m} / \mathrm{s}, 0.73 \mathrm{~m} / \mathrm{s}$ and $1.39 \mathrm{~m} / \mathrm{s}$, respectively.

The bars protecting the secondary bypasses entrances were replaced by rectangular cross-section bars to facilitate maintenance. Submerged nozzles, fed by a pump, were installed between the secondary bypasses gates and the protection bars to facilitate the removal of debris when the vertical bypass gates are closed.

\subsection{Radio telemetry procedures}

The smolts used were hatchery-reared smolts that were obtained from MIGADO hatchery in Castel, due to the difficulty of capturing wild smolts in the Dordogne river. The morphometric characteristics of smolts remained relatively
Table 1. Characteristics of radio-tracked smolts during the study period 2010-2016.

\begin{tabular}{lllllll}
\hline & Mean & Median & Min & Max & $\begin{array}{l}1 \text { st } \\
\text { quartile }\end{array}$ & $\begin{array}{l}\text { 3rd } \\
\text { quartile }\end{array}$ \\
\hline Length $(\mathrm{cm})$ & 19.4 & 19.3 & 15.2 & 23.2 & 18.5 & 20.4 \\
Weight $(\mathrm{g})$ & 63 & 62 & 31 & 110 & 53 & 72 \\
\hline
\end{tabular}

homogeneous during the different years of monitoring, with median values for length and weight of $19.3 \mathrm{~cm}$ and $62 \mathrm{~g}$ respectively (Tab. 1).

Marking operations during five of the seven years were carried out at the Tuilières plant; during the first two years, they took place at the Castel's hatchery. The fish to be marked at the dam were transported from the hatchery to the plant (about 200 per trip) where they were held in a tank of about $1.5 \mathrm{~m}^{3}$, permanently fed with the water from the Dordogne River until they were marked. Before any operations were conducted on the fish, they were first anaesthetized with a solution based on clove essential oil (10\% dilution). The fish were placed in a solution containing $1.5 \mathrm{ml}$ of eugenol diluted at $10 \%$ in ethanol for 101 of water. The smolts to be marked were selected according to criteria indicating good general condition and advanced smoltification state (uniform silver-coloured robe), weighed (to the nearest gram) and measured (total length, to the nearest millimetre). The radio transmitters were gastrically implanted.

The ATS $^{\circledR}$ (Advanced Telemetry Systems) radio transmitters used during the 2010 to 2015 campaigns had an individual frequency, transmitting in the $48 \mathrm{MHz}-49 \mathrm{MHz}$ range. Their characteristics were as follows: weight in air $1.4 \mathrm{~g}$, diameter $7 \mathrm{~mm}$, length $18 \mathrm{~mm}$, operating life between 10 and 15 days. In 2016, new transmitters similar to the previous transmitters, but coded ( 25 codes per frequency) and with a shorter lifetime (2-3 days) were used. The transmitter weight represented on average $2.3 \%$ of the weight of the smolts used in the study.

The fish were released in batches of 30, each batch including three marked fish. The fish were released from the Saint Capraise de Lalinde Bridge, located about $2 \mathrm{~km}$ upstream of the Tuilières dam. In order to compensate for a possible "bank effect", the releases were made successively from the right bank side (day d), the middle $($ day $d+1)$ and the left bank (day $\mathrm{d}+2$ ).

To get closer to the smolt's preferential night-time downstream migration conditions (Larinier and Travade, 1999), most releases took place at nightfall, between 8:40 p. m. and 9:50 p.m. However, several releases were made during the day to provide additional data for specific flow conditions.

\subsection{Radio telemetry antenna locations}

Fixed listening stations, consisting of a receiver (model ATS 2100) coupled to a $320 \mathrm{~KB}$ digital recorder (model ATS D5040 DCC), have been installed on different parts of the Tuilières plant. These stations, connected to receiving antennas, aerial (loop antenna) or underwater, allowed 


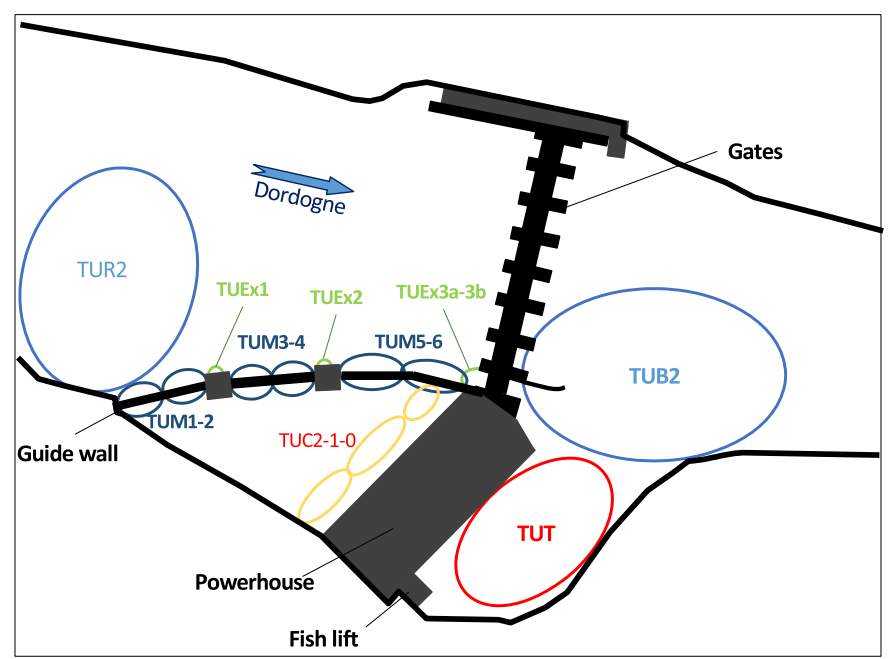

Fig. 4. Schematic diagram of the location of the radio-tracking recording zones.

continuous monitoring of calibrated reception zones and thus to accurately track the movements of tagged smolts. The listening time of a frequency was adjustable from $2 \mathrm{~s}$ to $16 \mathrm{~min}$. Given the potentially rapid travel velocity of downstream migrating smolts and feedback from other experiments (Larinier and Travade, 1999; Bau et al., 2002), this time was set at $4 \mathrm{~s}$ for this study. For each release, a manual tracking on foot was conducted up to the Tuilières dam to complete and corroborate the automatic radio monitoring. The various antennas installed on the site made it possible to discriminate 16 specific zones of different dimensions to observe the overall behaviour of tagged smolts on the study site, to determine the passage routes (turbines, bypasses, flood gates), as well as the passage times (Fig. 4). An aerial loop antenna delimiting a general upstream zone (TUR2) was installed to detect the arrival of smolts in the impoundment. The guide wall was fully equipped with underwater multiple antennas (TUM1 to TM6) to monitor the movement of the smolts and the eventual passage zone under the wall. The inner forebay was also equipped with three multiple underwater antennas (TUC0, TUC1 and TUC2) to monitor the behaviour between the guide wall and the trash rack of the powerhouse intake. The main surface bypass (FG) was equipped with two underwater antennas (TUEx3a and TUEx3b). Each secondary bypass was also equipped with a double-wire underwater antenna (TUEx1 and TUEx2). Finally, to confirm the passages through the turbines, a zone covering the turbine outlets was established (TUT and TUB2) using aerial loop antennas. Upstream and downstream detection zones on the left bank side were initially planned, but the Tuilières site is particularly parasitized by the presence of a 63,000-volt high-voltage line and proximity to transformers. In addition, the receivers/recorders used did not have efficient filters and the transmitters used were of low power compared to those used for eel or salmon adults. Therefore, the use of these detection zones was quickly abandoned. As the whole width of the reservoir was not covered, it was not always possible to detect the exact moment of fish arrival on site and therefore to determine the time spent on site before dam passage.
The data from the radio tracking enabled a number of quantitative passage metrics and behavioural descriptors to be established in order to determine the guide wall and bypasses performance.

On-site arrival time: the arrival time at the site corresponds to the time spent by the tagged smolts to travel between the release site and the vicinity of the guide wall of the Tuilières plant.

Residence time in the forebay: this time corresponds to the time between the time of the first detection of the fish, either during manual monitoring or by the upstream general antenna and the recorded time of the plant crossing.

Residence time in the inner forebay: this time corresponds to the time between the passage of the fish under the guide wall time and the recorded time of the plant crossing.

Transfer time: the transfer time of the smolts corresponds to the time spent between their release point and the recording of their crossing of the plant.

Escapement rate: percentage of detected fish passing through bypasses or gates compared with the total number of detected fish that passed the dam (through turbines, bypasses and gates).

\subsection{Environmental parameters}

The main environmental parameters (temperature, river discharge) were recorded on an hourly basis. The upstream and downstream water levels, the plant operation parameters likely to influence fish behaviour and the performance of the downstream migration facility were obtained from EDF at the time lapse of one minute, including: the turbine flows from the various units, the flow discharged by the main downstream bypass (FG), and the flows discharged by the floodgates or flap gates. The average daily flow in the Dordogne River was given by the Lamonzie Saint Martin gauging station located $25 \mathrm{~km}$ downstream of the plant.

\subsection{Study design}

The guide wall was monitored by radio-tracking for seven years during the smolt migration period in the spring (midMarch to mid-June). The results of the 2010-2013 experiments when the guide wall was in its original design will be distinguished, however, from those of the subsequent experiments 2014-2016 following the modifications of the wall. During the 2010-2013 monitoring period, 345 smolts were marked; of these, 297 were detected and their route identified at Tuilières. During the 2014-2016 monitoring period, 258 smolts were marked, 216 of which could be tracked (Tab. 2).

\section{Results (2010-2013)}

\subsection{Environmental conditions during experiments}

During these four years of tests, the Dordogne basin experienced only three significant rainfall events: late April and late May 2012 and late May-early June 2013 (Fig. 5).

In 2010, two significant flow increases occurred but in the beginning and towards the end of the study period. The first increase in flow occurred at the end of March-early April, the 
Table 2. Number of smolts tagged and period of tracking (2010-2016).

\begin{tabular}{lllll}
\hline Year & $\begin{array}{l}\text { No. of radio-marked } \\
\text { smolts released }\end{array}$ & $\begin{array}{l}\text { No. of radio tracked } \\
\text { smolts at Tuilières }\end{array}$ & $\begin{array}{l}\text { No. of batches } \\
\text { released }\end{array}$ & Period of tracking \\
\hline 2010 & 77 & 68 & 26 & From $01 / 04 / 10$ to $08 / 06 / 10$ \\
2011 & 66 & 62 & 22 & From 23/03/11 to 05/05/11 \\
2012 & 94 & 68 & 34 & From $15 / 03 / 12$ to $11 / 06 / 12$ \\
2013 & 108 & 99 & 39 & From $19 / 03 / 13$ to 05/06/13 \\
2014 & 86 & 72 & 30 & From 20/03//14 to 05/06/14 \\
2015 & 112 & 97 & 38 & From $17 / 03 / 15$ to 09/06/15 \\
2016 & 60 & 47 & 18 & From 23/03/16 to 02/05/16 \\
\hline
\end{tabular}

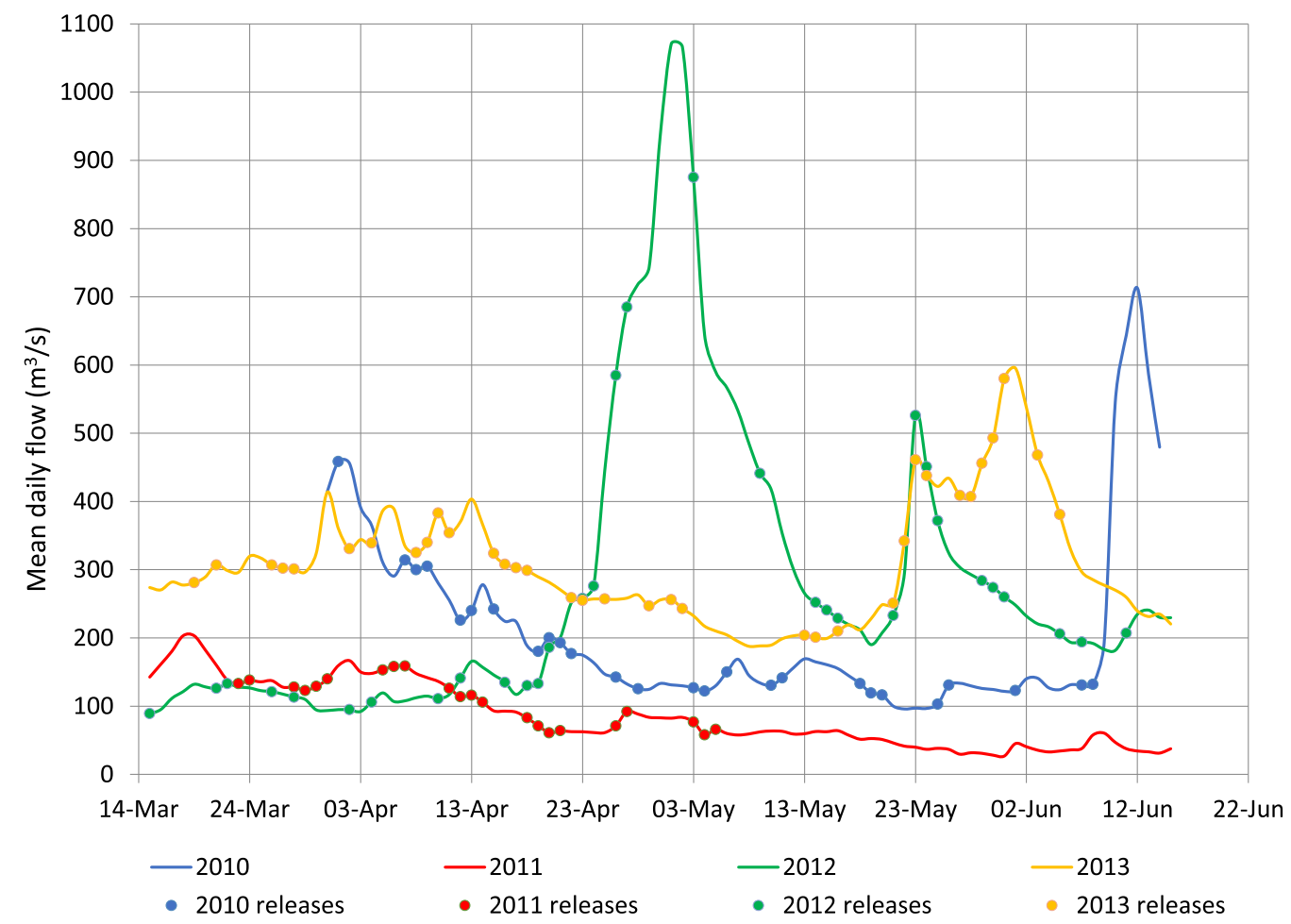

Fig. 5. Mean daily flows and days of release (2010-2013).

second when the downstream migration period was over. The Tuilières plant operated normally until April 12 (only three releases made before that date) before turbines 7 and 8 were forced out of operation for the rest of the monitoring period. However, this maintenance did not have a major impact on the study given the low flows observed since the end of April.

In 2011, flows remained very low, actually requiring the smolt releases to be stopped in early May, as the plant was almost shut down and the water temperature was high.

In 2012, the monitoring started with relatively low flows, before two increases of flow allowed releases to be made for flows higher than the mean interannual flow. The Tuilières plant operated normally during the downstream migration period.

In 2013, the sustained flows encountered from the first releases made possible the acquisition of a significant amount of data for flows larger than $200 \mathrm{~m}^{3} / \mathrm{s}$.

\subsection{Radio tag detections}

Of the 345 smolts marked during the 2010-2013 monitoring periods, $297(86 \%)$ were detected and their route identified at Tuilières: $68(88 \%)$ in 2010, $62(94 \%)$ in 2011, $68(72 \%)$ in 2012 and $99(92 \%)$ in 2013. The percentages were relatively low in 2012, as 26 individuals were never recorded at the study site. Regular manual monitoring on the study area and upstream of the release point has allowed a number of them (i.e. 4) to be found about $1.5 \mathrm{~km}$ upstream of the release point. Hydraulic conditions may also have had an important role in the loss of information. In the event of dam spills, it is possible that some fish may have passed directly through the flood gates (not equipped with radio antennas) without being detected during manual monitoring. 
M. Larinier et al.: Knowl. Manag. Aquat. Ecosyst. 2020, 421, 15

Table 3. Transfer time, on site arrival time, residence time in the forebay and in the inner forebay (2010-2013).

\begin{tabular}{lllllll}
\hline Time & No. of individuals & 1st decile & 1st quartile & median & 3rd quartile & 9th decile \\
\hline Transfer time (between release and crossing (hours) & 297 & 1.12 & 1.67 & 2.78 & 5.25 & 10.1 \\
Time between release and arrival on site (hours) & 157 & .82 & 1.0 & 1.33 & 1.7 & 2.28 \\
Residence time in the forebay (hours) & 157 & .12 & 0.18 & 0.38 & 0.97 & 2.99 \\
Residence time in the inner forebay (min) & 114 & 0.45 & 1.05 & 2.76 & 14.08 & 132 \\
\hline
\end{tabular}

Table 4. Passage routes at the Tuilières plant from 2010 to 2013.

\begin{tabular}{llllll}
\hline Year & 2010 & 2011 & 2012 & 2013 & Total \\
\hline No. of tracked smolts & 68 & 62 & 68 & 99 & 297 \\
Escapement (passage through bypasses or gates) & $33(49 \%)$ & $52(84 \%)$ & $46(68 \%)$ & $38(38 \%)$ & $169(57 \%)$ \\
Main bypass & $29(43 \%)$ & $42(68 \%)$ & $27(40 \%)$ & $22(22 \%)$ & $120(40 \%)$ \\
Secondary bypasses & $4(6 \%)$ & $10(16 \%)$ & $12(18 \%)$ & $2(2 \%)$ & $28(9 \%)$ \\
Gates & $0(0 \%)$ & $0(0 \%)$ & $7(10 \%)$ & $14(14 \%)$ & $21(7 \%)$ \\
Turbines & $35(51 \%)$ & $10(16 \%)$ & $22(32 \%)$ & $61(62 \%)$ & $128(43 \%)$ \\
\hline
\end{tabular}

\subsection{Travel and residence times, behaviour near the plant}

\subsubsection{On-site arrival time}

Except for a few individuals, the arrival time on site after the release was very short: median $1.33 \mathrm{~h}, 1 \mathrm{st}$ and $3 \mathrm{rd}$ quartiles respectively $1.0 \mathrm{~h}$ and $1.7 \mathrm{~h}$ (Tab. 3).

\subsubsection{Residence time in the forebay}

The median was $0.38 \mathrm{~h}$, the $1 \mathrm{st}$ and $3 \mathrm{rd}$ quartiles respectively $0.18 \mathrm{~h}$ and $0.97 \mathrm{~h}$. The "retention effect" of the structure seemed to be relatively limited as $90 \%$ of the recorded fish remained less than 3 hours in the forebay near the dam. Manual monitoring showed that the fish exhibited neither return behaviour, nor meandering pattern in the impoundment indicating that the fish were searching an outlet at the dam.

\subsubsection{Residence time in the inner forebay}

Once the wall was passed, the smolts generally remained only for a limited time in front of the trash rack: median time $2.76 \mathrm{~min}, 1 \mathrm{st}$ and $3 \mathrm{rd}$ quartiles respectively $1.05 \mathrm{~min}$ and $14.1 \mathrm{~min}$. However, some individuals remained in front of the screens for several hours before crossing them (9th decile $132 \mathrm{~min}$ ). The passage under the wall seemed irreversible as none of the 128 tagged smolts that crossed into the inner forebay, returned to the upstream side of the wall.

\subsubsection{Transfer time}

In contrast to the delays between release and arrival at the site or the residence time in the forebay, which could only be calculated for the individuals whose arrival time on-site could be detected (157 individuals), the 297 individuals of the sample were taken into account here. The median transfer time was $2.78 \mathrm{~h}$, the $1 \mathrm{st}$ and $3 \mathrm{rd}$ quartiles $1.67 \mathrm{~h}$ and $5.25 \mathrm{~h}$

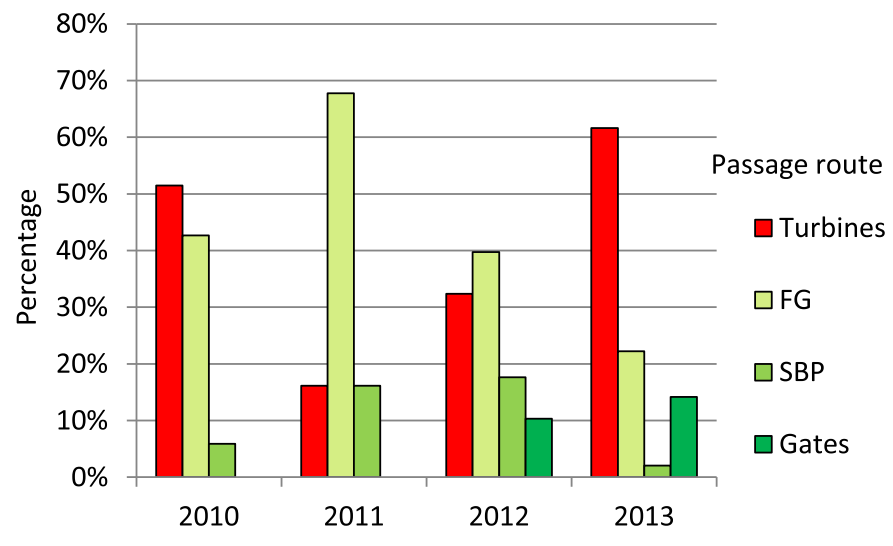

Fig. 6. Passage routes at the Tuilières plant (2010-2013).

respectively. Minimum and maximum were $0.18 \mathrm{~h}$ and $24 \mathrm{~h}$ respectively.

\subsection{Downstream passages and guide wall efficiency}

\subsubsection{Escapement rates and downstream routes}

Escapement rates (passage through a route other than turbines) varied considerably from year to year, from $38 \%$ in 2013 to $84 \%$ in 2011 , with an average of $57 \%$. The passage routes of the 297 radio-tagged smolts at the plant differed from year to year (Tab. 4), i.e. from $22 \%$ to $68 \%$ of the passages through the main surface bypass (flap gate FG), from $2 \%$ to $18 \%$ through the secondary bypasses (SBP), from 0 to $14 \%$ through the dam gates and from $16 \%$ to $62 \%$ through the turbines (Fig. 6). This variability in the results over the years (up to a factor of about 4 for turbine passages and 9 for secondary bypasses) can be explained by the particular flow conditions of each year. 


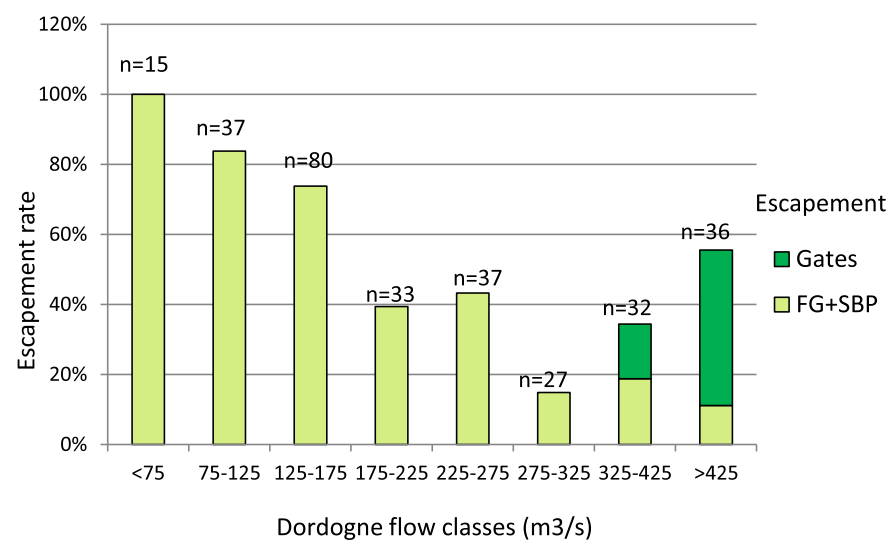

Fig. 7. Escapement rate (main and secondary bypasses, gates) vs total Dordogne River flow (2010-2013).

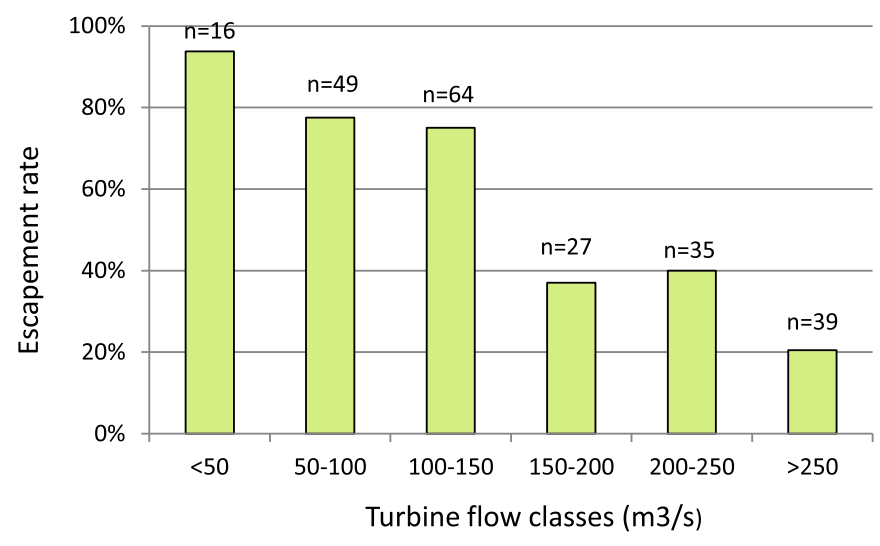

Fig. 8. Escapement rate (main and secondary bypasses) vs turbine flow (2010-2013).

\subsubsection{Effects of Dordogne river and turbine flows on escapement rates}

Calculated on the basis of the 297 radio marked smolts, the escapement rate by flow class of the Dordogne, pooled over the 4 years (Fig. 7), first clearly decreased with increasing flow in the Dordogne River, reaching a minimum around the maximum turbine-generating capacity of the plant (about $320 \mathrm{~m}^{3} / \mathrm{s}$ ), but then increased again as for higher flows, the opening of gates allowed some individuals to pass directly through the dam gates.

In the absence of spills at the dam and for turbine flows up to $150 \mathrm{~m}^{3} / \mathrm{s}$, more than $70 \%$ of the smolts present on the site crossed the Tuilières plant through the bypasses (FG or SBP) (Fig. 8). In contrast, for higher turbine flow, this percentage decreased and ranged from $20 \%$ to $40 \%$.

\subsubsection{Effect of turbine operation on downstream passages}

Although the flow patterns downstream of the guide wall are clearly related to the units in operation, it has not been

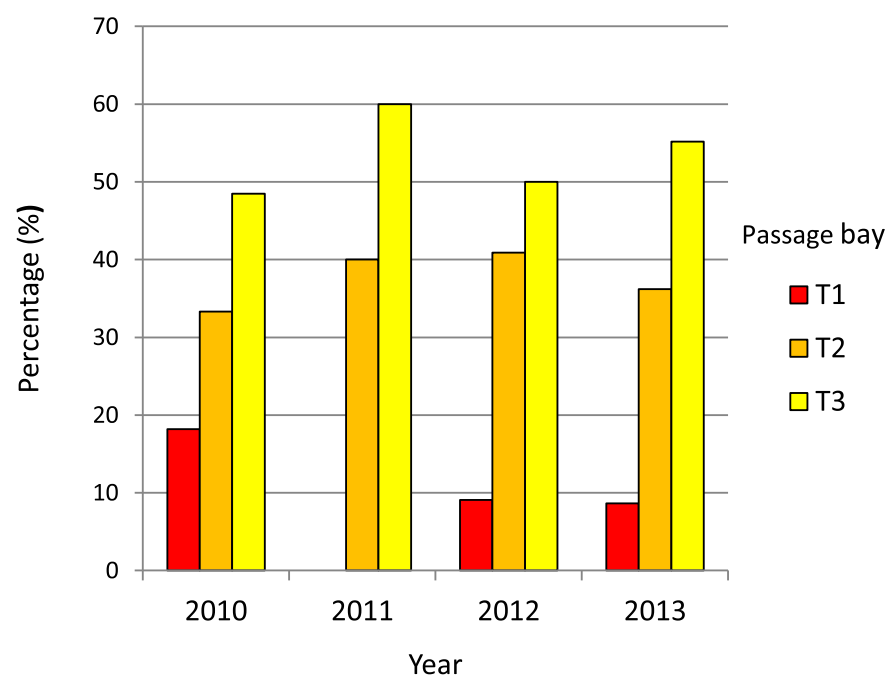

Fig. 9. Bays of passage vs year (2010-2013).

possible to identify, for equivalent turbine flows, any influence of the operation of particular units on either the escapement rate or the passage zone under the wall.

\subsubsection{Zones of wall passage according to the years}

The spatial distribution of the under-wall passage events of the smolts getting into the inner forebay and eventually passing through the turbines was relatively homogeneous among years (Fig. 9): passages were found to mostly occur at the two downstream sections T2 and T3. Between 33\% and $41 \%$ of the passages occur under the central section T2, and between $48 \%$ and $60 \%$ under the downstream section $\mathrm{T} 3$. The passages at the T1 upstream section were less important and more variable (from $0 \%$ to $17 \%$ ).

\subsubsection{Influence of the turbine flow on the wall passage zone}

The distribution of passages under the different wall sections, the flap gate (FG) and the secondary bypasses (SBP) varied with respect to turbine flows (Qtur). This distribution and its temporal variability, not including periods of spill at the dam (227 individuals), were examined (Fig. 10) for three turbine flow classes. Escapements through the flap gate or the secondary bypasses reach $61.5 \%$ and $20 \%$ respectively for Qtur $<100 \mathrm{~m}^{3} / \mathrm{s}$, they decrease to $28 \%$ and $3 \%$ respectively for Qtur $>200 \mathrm{~m}^{3} / \mathrm{s}$. Wall passages under the upstream section (T1) remain very low at all turbine flows $(<6 \%)$. On the other hand, crossing events at sections $\mathrm{T} 2$ and $\mathrm{T} 3$ increased drastically with flow, from $8 \%$ and $9 \%$ respectively for Qtur $<100 \mathrm{~m}^{3} / \mathrm{s}$ to $24 \%$ and $42 \%$ for Qtur $>200 \mathrm{~m}^{3} / \mathrm{s}$, and were at around $15 \%$ for the intermediate flow class.

\subsubsection{Arrival zones and passage routes: the wall guiding effect}

The arrival zone at the wall or bypasses was identified for 222 smolts, and was compared to their passage route (bays T1, $\mathrm{T} 2$ or $\mathrm{T} 3$ under the wall to the turbines, main bypass (FG) or 


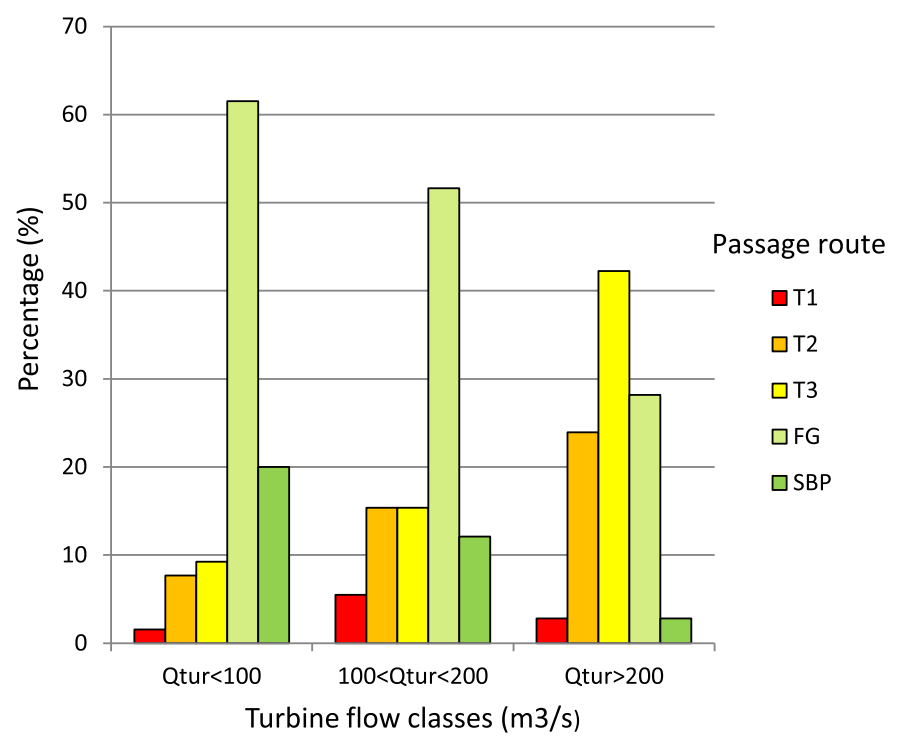

Fig. 10. Escapement rate by the different bays or bypasses vs turbine flow (2010-2013).

secondary bypasses (SBP)) when there was no spill at the dam. The fact that an individual does not cross the wall at its arrival bay but does so through a bay further downstream, through the flap gate or a secondary bypass is a good indication of the wall's ability to guide fish.

The passage routes (wall bays T1, T2 or T3, flap gate FG and secondary bypass SBP) have been reported for individuals arriving through a given zone, for the three flow classes (Fig. 11a-c).

For flows Qtur $<100 \mathrm{~m}^{3} / \mathrm{s}$, the escapement rate through $\mathrm{FG}$ or SBP of individuals arriving on bays $\mathrm{T} 2$ and $\mathrm{T} 3$ were respectively $60 \%$ and $80 \%$. These percentages were reduced to $41 \%$ and $57 \%$ respectively for class $100-200 \mathrm{~m}^{3} / \mathrm{s}$ and to $9 \%$ and $17 \%$ for class $>200 \mathrm{~m}^{3} / \mathrm{s}$ ).

The direct passage rates of the bay on which the individuals arrived were $20 \%$ for the bays T2 and T3 for the class Qtur $<100 \mathrm{~m}^{3} / \mathrm{s}$, and increase to $45 \%$ and $43 \%$ respectively, then to $65 \%$ and $83 \%$ for the two upper flow classes. With regard to the $\mathrm{T} 1$ bay, it was difficult to provide any rate of passage, given the very small number of individuals arriving in this zone (from $3 \%$ to $9 \%$ depending on the turbine flow).

These data showed that there was a marked guidance for turbine flows Qtur $<100 \mathrm{~m}^{3} / \mathrm{s}$, an effect that was still noticeable for the $100-200 \mathrm{~m}^{3} / \mathrm{s}$ class, but which became very low for higher flows.

\subsection{Attractiveness and efficiency of bypasses}

The areas delineated by the "flap gate" antennas (TUEx2 and TUEx3), which respectively extended from 6 to $9 \mathrm{~m}$ upstream of the flap gate, included the zone of hydrodynamic influence of the main downstream bypass. With the exception of 2010 when only $51 \%$ of the incursions into the main outlet area resulted in a passage by this bypass, the attractiveness of the main bypass seemed good. In 2011, 2012 and 2013, respectively $90 \%, 76 \%$ and $82 \%$ of the incursions into the main outlet area resulted in a passage through the bypass. Over all
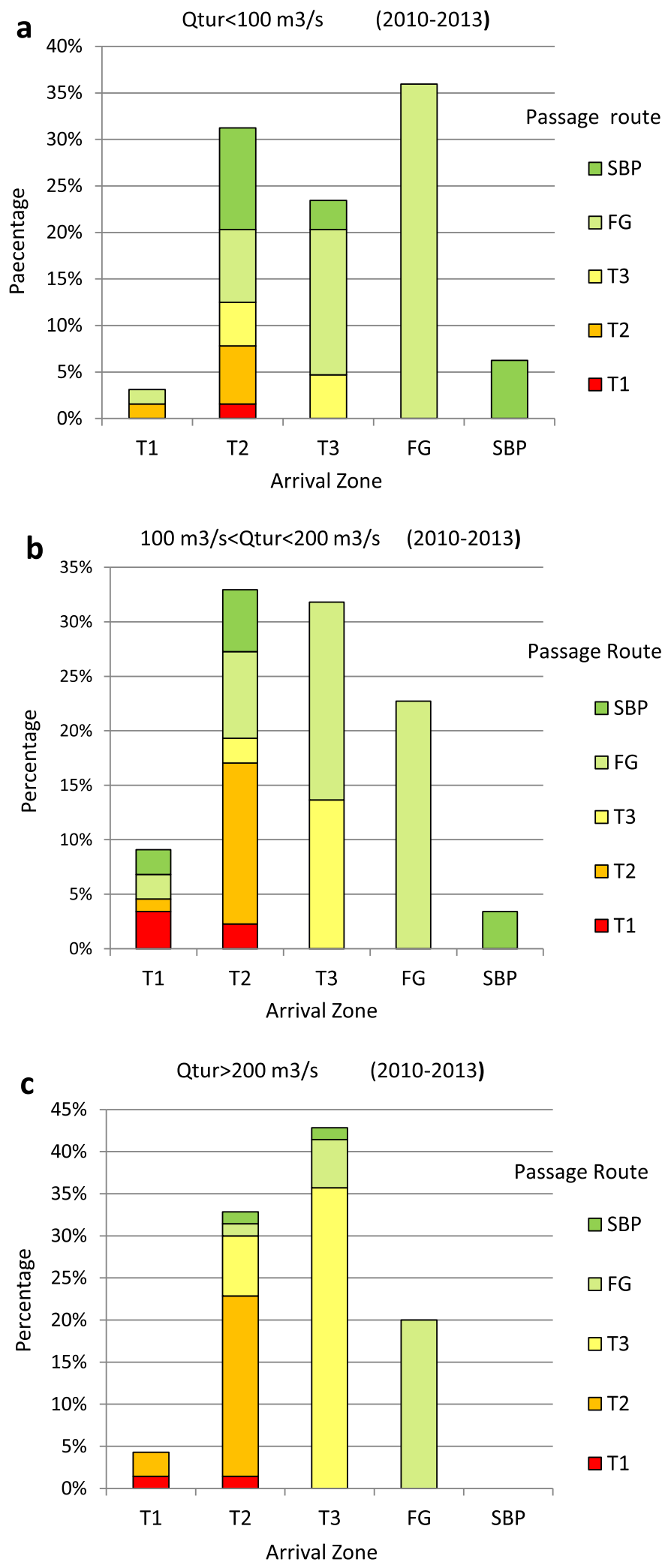

Fig. 11. Arrival zones and passage routes (2010-2013).

four years, the vast majority of individuals $(86 \%)$ passing the main bypass did so during their first visit, $96 \%$ with less than 4 visits. Furthermore, the residence times in this area were very 

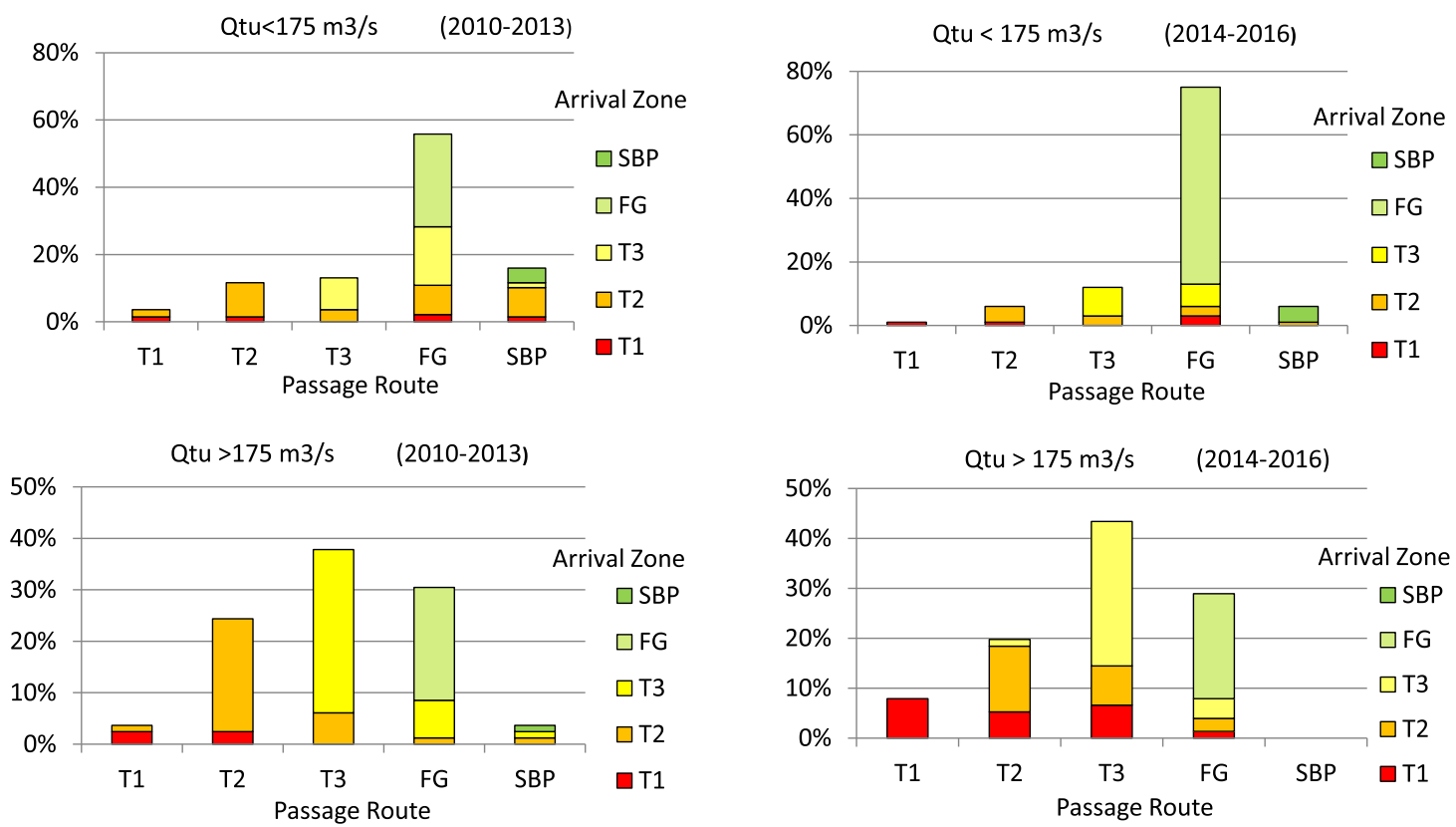

Fig. 12. Escapement rates, passage routes, arrival zones: comparison before (2010-2013) and after (2014-2016) guide wall modifications.

short. Out of 129 individuals, the average residence time is $169 \mathrm{~s}$, the median $35 \mathrm{~s}$, the $1 \mathrm{st}$ and 3 rd quartiles respectively $10 \mathrm{~s}$ and $94 \mathrm{~s}$.

Over the four years of experiments, only $9.5 \%$ of smolts used the secondary bypasses (28/297) and most of them under relatively low turbine flow conditions: $19 \%$ of the escapement occurred via the secondary outlets for turbine flows below $100 \mathrm{~m}^{3} / \mathrm{s}$, respectively $13 \%$ and $10 \%$ for the two upper flow classes.

\section{Results (2014-2016): changes in guide wall performance after modification}

During the 2014-2016 period, the smolt releases were concentrated for flow conditions for which it was critical to improve the guide wall efficiency given their frequency during migration, i.e. the $150-250 \mathrm{~m}^{3} / \mathrm{s}$ range. The escapement rates, the distribution of arrival zones and passages routes under the different wall sections, the flap gate (FG) and the secondary bypasses (SBP), were examined for two turbine flow classes, excluding periods of spill at the gates, before and after guide wall modifications (Fig. 12). The comparison was purely qualitative, the number of marked smolts (397 individuals) being insufficient to reveal significant differences between the two periods, even if some of these differences were marked.

The escapement rates after modification were higher $(81 \%$ vs. $72 \%$ ) for the lower turbine flow class (Qtur $<175 \mathrm{~m}^{3} / \mathrm{s}$ ) but they were close for the upper flow class (30\% vs. 34\%).

For the lower turbine flow class (Qtur $<175 \mathrm{~m}^{3} / \mathrm{s}$ ):

- Following the modification of the wall, a marked increase in the percentage of marked individuals detected for the first time at the main bypass was observed, representing $62 \%$ of the total passage (through the different bypasses and the turbines), and $76.5 \%$ of the overall escapement rate through the bypasses. Before modifications, these percentages were respectively $27.5 \%$ and $38.5 \%$.
- Correlatively, after modification, the percentages of arrivals at one of the three bays of the wall were lower, respectively $5 \%, 12 \%$ and $16 \%$ for bays $\mathrm{T} 1, \mathrm{~T} 2$ and T3 (vs. $6.5 \%, 33 \%$ and $28 \%$ before modification). Percentages of direct passage under the wall through the T2 and T3 bays increased after modification ( $42 \%$ and $56 \%$ vs. $30.5 \%$ and $33 \%$ before). As a result, the contribution to the escapement of individuals coming from bays T2 and T3 was much lower after modification, representing only $5 \%$ and $8.5 \%$ respectively, whereas it represented $24 \%$ and $26 \%$ of the overall escapement rate through the bypasses before modification.

The improvement in escapement rates following modification was essentially due to a much greater proportion of direct arrival of marked fish to the main bypass, despite a reduced wall effect.

For the upper flow class (Qtur $>175 \mathrm{~m}^{3} / \mathrm{s}$ ):

- The direct arrival rates at the main bypass were comparable before and after modification (respectively $22 \%$ and $21 \%$ ).

- The main change following the modification was a more uniform distribution of arrivals between the three bays: they increased clearly in bay T1 (21\% of arrivals vs. $5 \%$ before), whereas they correlatively decreased in T2 and T3 ( $24 \%$ and $34 \%$ vs. $32 \%$ and $40 \%$ before).

- Direct passage rates through bays T1 and T2 tend to decrease (respectively $38 \%, 55 \%$ for $2014-2016$ vs. 50\%, $69 \%$ for $2010-2013$ ) while they tend to increase through bay $\mathrm{T} 3$ following the modification (respectively $85 \%$ for 2014-2016 vs. 79\% for 2010-2013).

- The percentages of individuals arriving in T2 and T3 and guided up to the main bypass were respectively $11 \%$ and $11.5 \%$ for $2014-2016$ vs. $8 \%$ and $21 \%$ for $2010-2013$. After modification, none of individuals arriving in T1passed through the secondary bypasses and only $6 \%$ were guided up 


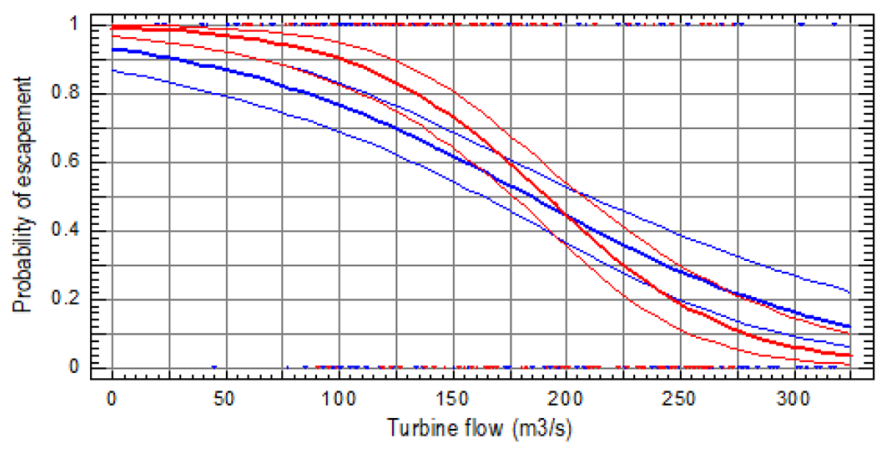

Fig. 13. Escapement probabilities via the bypasses (FG or SBP) as a function of turbine flow before (blue curve) and after (red curve) modifications.

to the main bypass (there were none before modification, but only a small number of individuals arrived in T1). This low escapement rate of the individuals arriving at $\mathrm{T} 1$ can partly explain the slight decrease in the guide wall performance for large turbine flows after modification.

\section{Logistical modelling of the escapement rate as a function of the turbine flow}

Escapement via bypasses (main and secondary bypasses) and passage through the turbines was modelled using logistic regression (Hosmer and Lemeshow, 2000). The variable Qtur (turbine flow in $\mathrm{m}^{3} / \mathrm{s}$ ) was used to explain the binary response variable (escapement via bypasses or passage via the turbines). The sample processed included the 230 smolts tracked from 2010 to 2013 and the 185 smolts tracked from 2014 to 2016 which passed the plant with no spill at the gates. The expression for the escapement probability (P) (i.e. passage via the bypasses) is:

$$
P=\exp (\eta) /(1+\exp (\eta))
$$

where $\eta=2.60-0.0141$ Qtur (before modification); $\eta=4.69$ 0.0245 Qtur (after modification).

Before modification, a chi-square test (chi-square $=2.28$ with 3 degrees of freedom, $p=0.516$ ) shows that with a confidence level of $95 \%$, there is no reason to reject the model's goodness of fit, since the probability is greater than or equal to 0.05 .

After modification, the chi-square test (chi-square $=3.83$ with 3 degrees of freedom, $p=0.280$ ) shows that with a confidence level of $95 \%$, there is no reason to reject the model's goodness of fit, since the probability is greater than or equal to 0.05 .

Both logistical curves highlight the slight increase in escapement rates for turbine flows below $150-200 \mathrm{~m}^{3} / \mathrm{s}$ (Fig. 13).

\section{Logistical modelling of the passage under the wall as a function of the average flow velocity under the wall}

Passage or no-passage under the wall of marked individuals at the time of their first detection at the wall
(2010-2016)

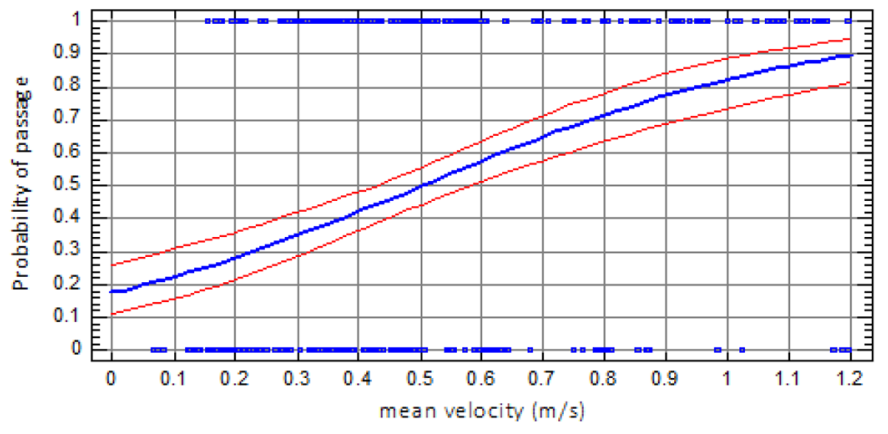

Fig. 14. Probabilities of direct passage under the wall (via T1, T2 or $\mathrm{T} 3)$ as a function of average velocity through the bay (2010-2016).

antennas was modelled using logistic regression. The mean velocity variable $V_{m}(\mathrm{~m} / \mathrm{s})$ through the bay at the time of fish arrival was used to explain the binary response variable (passage or not under the wall). Mean velocities were estimated using instantaneous turbine flow and the flow distribution between the bays measured in the scale model. The sample processed included 348 smolts tracked from 2010 to 2016. The expression for the escapement probability (P) (i.e. passage via the bypasses) is:

$$
P=\exp (\eta) /(1+\exp (\eta))
$$

where $\eta=-1.55+3.086 V_{m}$.

A chi-square $=6.00$ with 5 degrees of freedom, $p=0.306$ shows that with a confidence level of $95 \%$, there is no reason to reject the model's goodness of fit, since the probability is greater than or equal to 0.05 .

The probability of direct passage under the wall for a mean velocity $V_{m}$ under a bay of $0.50 \mathrm{~m} / \mathrm{s}$ is approximately 0.5 (Fig. 14), and is below 0.25 for average velocities about $0.15 \mathrm{~m} / \mathrm{s}$.

\section{Discussion}

The objective of these seven years of experiments was to test the ability of a partial-depth guide wall to divert downstream migrating salmon smolts towards surface bypasses. The results of the monitoring carried out from 2010 to 2013, with an initial configuration of the guide wall, show that the escapement rate (passage by the three surface bypasses or the gates) varies greatly with the flow of the Dordogne River. While it remains above $75 \%$ for turbine flows below $150-175 \mathrm{~m}^{3} / \mathrm{s}$, this rate then decreases rapidly to values around $20 \%$ for flows close to the plant's maximum turbine capacity. For higher flows, there is again an increase in escapement rates due to direct passages through the dam gates.

Escapement occurs mainly through the main bypass (the flap gate), with the ratio passage secondary bypasses/flap gate decreasing with turbine flow: from $1 / 3$ for turbine flows below $100 \mathrm{~m}^{3} / \mathrm{s}$ to $1 / 10$ for turbine flows above $200 \mathrm{~m}^{3} / \mathrm{s}$.

The attractiveness of the main bypass appears to be good, as the majority of smolts that entered the "area of the flap gate antennas", i.e. at a distance of about 7 metres upstream of the flap gate, passed through it. This zone more or less corresponds to the flap gate's zone of influence, that is the "decision zone", 
as defined by Johnson and Dauble (2006), where the smolt chooses whether or not to pass downstream. The passage under the guide wall is irreversible since none of the smolts that crossed it from upstream to downstream took the opposite way out of the inner forebay.

A high proportion (20-38\%) of the first arrivals are recorded directly at the main bypass (FG), which means that these fish do not get close to the immediate proximity of the wall. This phenomenon is all the more marked as the turbine flows are low.

The arrival of fish to the wall occurs mainly at the two downstream sections of the wall (T2 and T3), with less than $10 \%$ over the years 2010-2013 occurring at the upstream section (T1). The guiding of fish along the wall from one section to the next, and from the last section downstream to the flap gate, is obvious for turbine flows below $100 \mathrm{~m}^{3} / \mathrm{s}$. For turbines flows above $200 \mathrm{~m}^{3} / \mathrm{s}$, the guidance becomes much less evident, the large majority of fish (from 65\% to $83 \%$ ) dive under the wall in the same bay they have arrived.

The modification of the mask in 2014, consisted mainly of an increase in the immersion depths, respectively $0.85 \mathrm{~m}$ and $1.65 \mathrm{~m}$ for wall sections $\mathrm{T} 2$ and $\mathrm{T} 3$. It resulted in a slight increase in the escapement rates for lower turbine flows $(5 \%$ to $10 \%$ more), which was essentially due to a much greater proportion of fish arriving directly at the main bypass. On the other hand, it did not improve the performance of the wall at higher turbine flows, even though this was the primary objective of the modification.

Direct passage rates of fish under the wall seem to be linked to the mean flow velocity under the wall, as the surface velocity parallel to the wall remained very low, between $0.10 \mathrm{~m} / \mathrm{s}$ and $0.20 \mathrm{~m} / \mathrm{s}$ regardless of the turbine flow. This was particularly noticeable for the T3 bay, with the direct passage under the wall rising from $20 \%$ to $85 \%$, while the average velocity under the mask passed from $0.20-0.30 \mathrm{~m} / \mathrm{s}$ to $0.75-1.00 \mathrm{~m} / \mathrm{s}$.

The six years of monitoring have made it possible to derive a logistic equation defining the probability of direct passage at the arrival bay as a function of the average velocity under the wall, which would be of the order of 0.5 for a mean velocity of $0.50 \mathrm{~m} / \mathrm{s}$. This probability curve is specific to the local conditions of Tuilières and most definitely cannot be extrapolated to other sites. It is indeed very probably related to the low value of the velocities parallel to the wall.

Actually in Tuilières, the mask only effectively fulfilled its function as a guide at low turbine flows, i.e. when the velocities parallel to the wall and average velocities under the mask were of the relatively same order of magnitude. The increase in the immersion depth of the wall as a result of the modification seems to have had an overall more negative effect on the performance of the guide wall by increasing the velocity under the wall than a positive effect by forcing the fish to dive at greater depths in order to pass.

Like other guidance devices, the efficiency of a partialguide wall is related to the rheotactic response of the fish, i.e. the modification of its trajectory in response to the variation in the velocity field induced by the device. The major difference between a partial-depth guide wall and more traditional guidance devices is that the wall can only operate at a limited depth, corresponding more or less to its immersion depth, with the lower part remaining free for flow and fish passage. The depth of the wall must be at least greater than the swimming depth preference of most individuals of the target species, which is unfortunately generally not known and may even vary according to location (in relation to dam) and diel period (between day and night) (Li et al., 2015). On the other hand, the efficiency of the guide wall on downstream migrating fish in a zone influenced by the presence of the wall will be related to the existence of a velocity component parallel to the guide wall, a component sufficiently marked to induce the fish to move or be entrained to the bypass. Otherwise, the fish will finally dive and pass under the mask. Even if Atlantic salmon smolts are known to migrate in the surface layer (Rivinoja, 2005), experience shows that when they lose surface hydraulic cues, they may let themselves be drawn into the flow, or even dive to depths greater than a dozen metres to find a route.

The ease of fish passage under the wall increases with increasing flow velocity under the wall. This velocity, for a given flow, will be all the more important as the passage section under the wall is reduced, i.e. its immersion depth high and its length limited.

The design criteria for a guide wall should take into account (i) the swimming depth preference of the relevant species during its downstream migration, which will define a minimum immersion depth of the guide wall, (ii) a maximum velocity below the guide wall (iii) a minimum parallel velocity to the guide wall and/or a maximum ratio parallel velocity/flow velocity below the guide wall and (iv) flow conditions at the transition between the downstream end of the guide wall and the bypass entrance ensuring an efficient transfer from the wall end to the surface bypass (i.e. gradual water acceleration, no "dead" zone).

A minimum wall depth immersion could be defined on the basis of installations that have demonstrated a high degree of efficiency, linked not only to a sufficient immersion depth but also to a priori favourable hydraulic conditions. In the case of Tuilières, the $4.07 \mathrm{~m}$ wall depth, despite low velocities along the wall, ensures a clear (but far from total) guidance at low turbine flows. But after modification, the downstream section of the wall, despite an immersion depth increased from 4.07 to $5.72 \mathrm{~m}$, appears to be as penetrable as before modification for high turbine flows. On the Bellows Falls plant (Hanson, 1999), a $4.60 \mathrm{~m}$ immersion guide wall, associated with apparently favourable hydraulic conditions (guide wall installed in a canal, see below), proved to be very effective $(84 \%)$. On the Piteälven River in Sweden, a floating wall with a relatively shallow immersion depth $(2 \mathrm{~m})$, associated with apparently favourable hydraulic conditions (see below) proved to be very effective, guiding $85 \%$ of the marked individuals (Vikström, 2016). In contrast, on the Gave de Pau in France, the efficiency of a $1 \mathrm{~m}$ submerged boom, installed under a priori suitable hydraulic conditions (floating boom installed at $45^{\circ}$ in a narrow canal, high sweeping velocities) was found to be limited (around 22\%), with most smolts passing directly under the boom (Bau et al., 2002).

With regards to the flow velocity under the wall, a good reference would be, as also applicable for fish screens of a power plant, to remain far below the maximum cruising speed of the target species, i.e. around $0.50-0.60 \mathrm{~m} / \mathrm{s}$ for Atlantic salmon smolt (Larinier and Travade, 2002), so as to give the fish the possibility to regain the surface layers if they are caught in the flow zone passing under the mask. Rakowski et al. (2006) in their CFD study on the implementation of a 
BGS (Behavioral Guidance System) in the impoundment of the The Dalles dam in the USA, adopted as a benchmark the maximum value of $0.60 \mathrm{~m} / \mathrm{s}$ for juvenile Pacific salmon and Steelhead trout, following the experience gained on the BGS installed at Lower Granite dam (Adams et al., 2001).

On the other hand, the velocity under the mask must remain consistent with the sweeping velocity, as shown in Tuilières.

With regard to the flow velocity along the wall, we could use analogies with criteria used for devices such as angled screens and more generally guiding devices, where tangential velocities equal or higher than the normal component to the screen plane are sought (Courret and Larinier, 2008; Raynal et al., 2013). Rakowski et al. (2006) mentioned as a guide value a lateral flow greater the perpendicular flow directed at the wall.

The possibility of implanting a wall that has a favourable angle of incidence for the creation of a sufficient lateral flow depends above all on the general flow patterns in the forebay. The most appropriate situation is when the power plant is installed in a headrace with no spillway, the general direction of flow then coinciding more or less with the direction of the channel. This corresponds to the idealized power canal modelled by Mulligan et al. $(2017,2018)$ in their CFD and laboratory study on guide walls. The only example of such a configuration that has been evaluated by radio telemetry is the guide wall installed in the inlet channel of the Bellows Falls power plant on the Connecticut River in the USA (Hanson, 1999). The power station hydraulic capacity is $298 \mathrm{~m}^{3} / \mathrm{s}$. A floating $\log$ /ice boom was replaced in 1994 by a $63 \mathrm{~m}$ long guide wall, angled at $40^{\circ}$ to the axis of the intakes channel and extending to mid-depth, $4.6 \mathrm{~m}$ below the normal upstream water level. This wall diverts fish to an outfall channel with a flow rate of $7.1 \mathrm{~m}^{3} / \mathrm{s}$. The efficiency of the guide wall itself was estimated during a radio telemetry campaign at $84 \%$. The evaluation was carried out under the most adverse conditions, with the plant operating most often during the experiment at full hydraulic capacity. As in Tuilières, it should be noted that the passage under the wall is irreversible: no individual, once in the inner forebay, returned to the upstream side of the guide wall.

The conditions for installing a guide wall are much less favourable when the forebay includes both spillway and powerhouse structures. This is the case of Tuilières where the power plant occupies only one third of the width of the hydropower development. Part of the flow supplying the powerplant comes from the opposite side of the forebay and arrives almost perpendicular to the direction of the guide wall, even if this wall has a low incidence with the bank. As a result, the velocity component parallel to the wall is not very marked and does not exceed $0.10 \mathrm{~m} / \mathrm{s}$ to $0.20 \mathrm{~m} / \mathrm{s}$. This may explain the difference in efficiency between the Bellows Falls and Tuilières sites. At Tuilières the efficiency only reaches a value similar to that of Bellows Falls for flows below $150 \mathrm{~m}^{3} / \mathrm{s}$, with flows passing through the bypass in proportion to the turbine-flows much higher than those allocated to Bellows Falls $\left(21 \mathrm{~m}^{3} / \mathrm{s}\right.$ vs. $\left.7 \mathrm{~m}^{3} / \mathrm{s}\right)$. This difference in efficiency cannot be attributed to the depth of the wall (almost identical) or to the flow conditions under the wall, as the average velocity are of the same order of magnitude, but more likely to a sweeping velocity, much less marked at Tuilières than at Bellows Falls.
It is clear that the magnitude of the sweeping velocity, and the diversion efficiency of a guide wall also depends on the proportion of the stream flow that passes from one side of the wall to the other. In Tuilières, the escapement rates gradually decrease with the turbine flow as long as the flow allowing the fish to escape remains limited to the flow of the surface bypasses, but they increase when there is a significant spill at the gates of the dam. This is similar to the problem of floating guide walls installed in impoundments designed to intercept downstream migrating juveniles and to divert them to an area that is likely to be more favourable to their survival (spillways rather than turbines). On the Piteälven River in Sweden, a floating wall was installed across the entire width of the reach upstream of Sikfors generating station (Vikström, 2016) to direct Atlantic salmon smolts towards spillways. The device proved to be relatively effective, guiding $85 \%$ of the marked individuals on the spillway side, and only letting $15 \%$ pass through on the turbine side. However, this result can be explained by a quasi-equipartition of flows on both sides of the device during the experiment $\left(250 \mathrm{~m}^{3} / \mathrm{s}\right.$ on the turbine side and $250 \mathrm{~m}^{3} / \mathrm{s}$ on the spillway side).

The above examples show the challenge of defining design criteria for a guide wall. The two parameters velocities under the wall and sweeping velocities are strongly related to the geometry of the wall and its depth of immersion, but also to the configuration of the forebay and the plant, the hydraulic conditions in the forebay and their variability. Research has been carried out from a purely hydraulic point of view on partial-depth guide walls (Mulligan et al., 2017, 2018), but as the authors note in the conclusion, only a better understanding of fish behaviour can lead to real-world application of these CFD or hydraulic scale models. This was the main interest of experiments such as those carried out in Tuilières, which, in addition to the need to comply with regulatory requirements, makes it possible to better assess the fish behaviour. The main limit of the experiment was the technique used (radio-tracking) and the site constraints that did not allow for the definition of the fish trajectories in the forebay and their position in the water column. The results would have been more meaningful, in particular allowing a better understanding of the behaviour of smolts in front of the wall, had 3D hydroacoustic telemetry been used, as fish swimming depth is the critical parameter for the device tested. It is indeed critical to understanding how juvenile salmon respond to a structure such as a guide wall, under which conditions the fish actively or passively follow the current lines and pass under the wall or remain on the surface layers and allow themselves to be carried towards a safe passage downstream. Such studies on fish behaviour, carried out over several migration seasons, must imperatively be accompanied by a simultaneous collection of hydraulic data, which would allow for an analysis of the relationship between fish behaviour and specific hydraulic conditions. This type of study is essential to define the interest and the limitation of the use of partial-depth guide walls for the hydropower stakeholders, to help engineers and biologists to optimize the shape and the features of such devices, to define the number, the location, the features of the bypasses and how much flow they require.

Acknowledgments. The authors would like to thank EDF GEH Dordogne for permission to set up and conduct this study, 
and the staff at the Tuilières power plant (J.M. Quadjovie, A. Courbier, E. Gandreau, E. Lascaux, N. Yakhlef and F. Vaché) for their contribution and collaboration all along the study. This work would have not been possible without the diligent effort of the staff of ECOGEA, who tagged and tracked smolts, maintained, downloaded receivers and managed the telemetry database over the course of this study. Thanks to the association MIGADO (MIgrateurs GAronne DOrdogne) for providing us with quality smolts. We would also like to thank the Ecohydraulics Pole of the French Biodiversity Agency and the EDF Research \& Development Division in Chatou for their contribution in the radiotracking installation and equipment, the members of the Tuilières scientific committee for their role as an advisor to the French government and to EDF. Special thanks to $\mathrm{D}^{\mathrm{r}}$ Gerd Marmulla and to two anonymous reviewers for valuable and constructive comments. Funding was provided by EDF.

\section{References}

Adams NS, Johnson GE, Rondorf DW, Anglea SM, Wik TO. 2001. Biological Evaluation of the Behavioral Guidance Structure at Lower Granite Dam on the Snake River, Washington in 1998. In: Coutant C, ed. Behavioral Technologies for Fish Guidance, American Fisheries Society Symposium, 26, Bethesda MD, 145-160.

Bau F, Chanseau M, Larinier M. 2002. Evaluation de l'efficacité d'une drome de dévalaison «Fishfree » pour smolts de saumon atlantique au niveau de l'aménagement hydroélectrique de VIZENS (Gave de Pau), Rapport GHAAPPE RA02.02, 40 p.

Calles O, Rivinoja P, Greenberg L. 2013. A Historical Perspective on Downstream Passage at Hydroelectric Plants in Swedish Rivers. In Maddock I, Harby A, Kemp P, Wood P, eds. Ecohydraulics: An Integrated Approach. John Wiley \& Sons, Ltd. pp. 309-321.

Cefas A. 2012. Assessment of Damage to Smolts Caused by Archimedes Screw Hydropower Turbines. Lowestoft: T.R.I. Potter, P. Davison \& A. Moore.

Clay CH. 1995. Design of fishways and other fish facilities. Second Edition. Boca Raton, FL: Lewis Publishers, 248 p.

Courret D, Larinier M. 2008. Guide pour la conception de prises d'eau "ichtyocompatibles" pour les petites centrales hydroélectriques. Rapport GHAAPPE RA.08.04., Agence de l'environnement et de la maîtrise de l'énergie, $72 \mathrm{p}$.

Hanson BN. 1999. Effectiveness of two surface bypass facilities on the Connecticut river to pass emigrating Atlantic Salmon smolts. In: Odeh M. ed. Innovations in fish passage technologies. Bethesda, MD: American Fisheries Society, pp. 43-60.

Hosmer DW, Lemeshow S. 2000. Applied Logistic Regression. New York: John Wiley \& Sons, 375 p.

Johnson GE, Dauble DD. 2006. Surface flow outlets to protect juvenile salmonids passing through hydropower dams. Rev Fish Sci 14: $213-244$.

Lagarrigue T. 2013. Tests for evaluating damage to fish species migrating downstream during their transit through the VLH hydraulic turbine installed on the Tarn River in Millau. Report ECOGEA, Toulouse, $23 \mathrm{p}$.

Lagarrigue T, Frey A. 2010. Test for evaluating the injuries suffered by downstream-migrating eels in their transit through the new spherical discharge ring VLH turbogenerator unit installed on the Moselle river in Frouard. Report ECOGEA, Toulouse, 26 p.
Larinier M. 2008. Fish passage experience at small-scale hydroelectric powerplants in France. Hydrobiologia 609: 97-108.

Larinier M, Dartiguelongue J. 1989. La circulation des poissons migrateurs : le transit à travers les turbines des installations hydroélectriques. Bull Fr Pêche et Piscic 312-313: 90 p.

Larinier M, Travade F. 1999. The development and evaluation of downstream bypasses for juvenile Salmonids at small scale hydroelectric plants in France. In: Odeh M. ed. Innovations in fish passage technologies. Bethesda, MD: American Fisheries Society, $25-42$.

Larinier M, Travade F. 2002. Downstream migration: problems and facilities. Bull Fr Pêche Piscic 364 Suppl.: 181-207.

Limburg KE, Waldman JR. 2009. Dramatic declines in North Atlantic diadromous fishes. BioScience 59: 955-965.

Li X, Deng ZD, Brown RS, et al. 2015. Migration depth and residence time of juvenile salmonids in the forebays of hydropower dams prior to passage through turbines or juvenile bypass systems: implications for turbine-passage survival. Conserv Physiol 3: 2-17.

Mulligan K, Towler B, Haro A, Ahlfeld D. 2017. A computational fluid dynamics modeling study of guide walls for downstream fish passage. Ecol Eng 99: 324-332.

Mulligan K, Towler B, Haro A, Ahlfeld D. 2018. Downstream fish passage guide walls: a hydraulic scale model analysis. Ecol Eng 115: $122-138$.

Nyqvist D, Nilsson P, Alenäs I, et al. 2017. Upstream and downstream passage of migrating adult Atlantic salmon: remedial measures improve passage performance at a hydropower dam. Ecol Eng 102: 331-343.

Odeh M. 1999. Fish passage Innovation for Ecosystem and Fishery restoration. In : Odeh $M$. ed. Innovations in Fish Passage Technology. Bethesda, MD: American Fisheries Society, 1-24.

Odeh M, Orvis C. 1998. Downstream fish passage design considerations and developments at hydroelectric projects in the North-east USA. In Jungwirth M, Schmutz S, Weiss S. eds. Fish Migration and Fish Bypasses, Fishing News Books, 267-280.

Ovidio M, Dierckx A, Bunel S, Grandry L, Spronck C, Benitez JP. 2017. Poor performance of a retrofitted downstream bypass revealed by the analysis of approaching behaviour in combination with a trapping system. River Res Appl 33: 27-36.

Pallo S, Larinier M. 2002. Définition d'une stratégie de réouverture de la Dordogne et de ses affluents à la dévalaison des salmonidés grands migrateurs. Simulation des mortalités induites par les aménagements hydroélectriques lors de la migration de dévalaison. Rapport GHAAPPE RA.02.01, 65 p.

Rakowski CL, Richmond MC, Serkowski JA, Johnson GE. 2006. Forebay computational Fluid Dynamics Modeling for The Dalles Dam to Support Behavior Guidance System Siting Studies. Pacific Northwest National Laboratory, report PNNL-15689, 158 p.

Raynal S, Chatellier L, Courret D, Larinier M, David L. 2013. An experimental study on fish-friendly trashracks - Part 2. Angled trashracks, J Hydraulic Res 51: 67-75.

Rivinoja P. 2005. Migration problems of Atlantic salmon (Salmo salar L.) in flow regulated rivers. Acta Universit Agric Sueciae 114: $1-36$.

Thorstad EB, Whoriskey F, Uglem I, Moore A, Rikardsen AH, Finstad B. 2012. A critical life stage of the Atlantic salmon Salmo salar: behaviour and survival during the smolt and initial post-smolt migration. J Fish Biol 81: 500-542.

Thorstad, EB, Havn TB, Sæther SA, Heermann L, Teichert MA, Diserud OH. 2017. Survival and behaviour of Atlantic salmon smolts passing a run-of-river hydropower facility with a movable bulb turbine. Fish Manag Ecol 24: 199207. 
Tomanova S, Courret D, Alric A, Oliveira E, Lagarrigue T, Têtard S. 2018. Protecting efficiently sea-migrating salmon smolts from entering hydropower plant turbines with inclined or oriented low bar spacing racks. Ecol Eng 122: 143-152.

Travade F, Dartiguelongue J, Larinier M. 1987. Dévalaison et franchissement des turbines et ouvrages énergétiques : l'expérience EDF. La Houille Blanche 1-2: 135-142.

Travade F, Larinier M, Boyer-Bernard S, Dartiguelongue J. 1998. Performance of four fish pass installations recently built on two rivers in South-West France. In Jungwirth M, Schmutz S, Weiss S, eds. Fish migration and fish bypass channels, Vienne, 146-170.

Vikström L. 2016. Effectiveness of a fish-guiding device for downstream migrating smolts of Atlantic salmon (Salmo salar L.) in the River Piteälven, northern Sweden. Swedish University of Agricultural Sciences. Faculty of Forest Science Department of Wildlife, Fish, and Environmental Studies. Examensarbete i ämnet biologi: $10,30 \mathrm{p}$.

Cite this article as: Larinier M, Dumond L, Lagarrigue T, Frey A, Travade F. 2020. Performance of a large partial-depth guide wall to divert downstream migrating Atlantic salmon smolts at Tuilières dam, Dordogne River. Knowl. Manag. Aquat. Ecosyst., $421,15$. 